University of Wollongong

Research Online

Faculty of Engineering - Papers (Archive)

Faculty of Engineering and Information

Sciences

2004

\title{
Effects of Nanosized Adsorbing Material on Electrochemical Properties of Sulfur Cathodes for Li/S Secondary Batteries
}

\author{
M. S. Song \\ Korea Advanced Institute of Technology, Korea \\ S. C. Han \\ Korea Advanced Institute of Technology, Korea \\ H. S. Kim \\ Korea Advanced Institute of Technology, Korea \\ J. H. Kim \\ Korea Advanced Institute of Technology, Korea \\ K. T. Kim \\ Korea Advanced Institute of Technology, Korea
}

See next page for additional authors

Follow this and additional works at: https://ro.uow.edu.au/engpapers

Part of the Engineering Commons

https://ro.uow.edu.au/engpapers/113

\section{Recommended Citation}

Song, M. S.; Han, S. C.; Kim, H. S.; Kim, J. H.; Kim, K. T.; Kang, Y. M.; Ahn, H. J.; Dou, S. X.; and Lee, J. Y.: Effects of Nanosized Adsorbing Material on Electrochemical Properties of Sulfur Cathodes for Li/S Secondary Batteries 2004.

https://ro.uow.edu.au/engpapers/113

Research Online is the open access institutional repository for the University of Wollongong. For further information contact the UOW Library: research-pubs@uow.edu.au 


\section{Authors}

M. S. Song, S. C. Han, H. S. Kim, J. H. Kim, K. T. Kim, Y. M. Kang, H. J. Ahn, S. X. Dou, and J. Y. Lee 
Journal of The Electrochemical Society, 151 (6) A791-A795 (2004)

\title{
(4hS) \\ Effects of Nanosized Adsorbing Material on Electrochemical Properties of Sulfur Cathodes for Li/S Secondary Batteries
}

0013-4651/2004/151(6)/A791/5/\$7.00 (C) The Electrochemical Society, Inc.

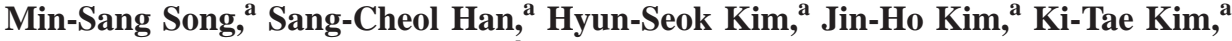 \\ Yong-Mook Kang, ${ }^{a}$ Hyo-Jun Ahn, ${ }^{b, *}$ S. X. Dou, ${ }^{c}$ and Jai-Young Lee ${ }^{\mathrm{a}, \mathrm{z}, *}$ \\ ${ }^{a}$ Department of Materials Science and Engineering, Korea Advanced Institute of Science and Technology, \\ Yusong-gu, Daejon 305-701, Korea \\ ${ }^{b}$ Department of Metallurgical and Materials Engineering, Gyeongsang National University, Jinju, \\ Gyeognam 660-701, Korea \\ ${ }^{c}$ Institute for Superconducting and Electronic Materials, University of Wollongong, \\ Wollongong NSW 2522, Australia
}

In order to prevent polysulfide dissolution into liquid electrolytes and to promote the $\mathrm{Li} / \mathrm{S}$ redox reaction (16Li $+\mathrm{S}_{8} \leftrightarrow \mathrm{Li}_{2} \mathrm{Sn} \leftrightarrow \mathrm{Li}_{2} \mathrm{~S}$ ), nanosized $\mathrm{Mg}_{0.6} \mathrm{Ni}_{0.4} \mathrm{O}$, which has the catalytic effect of chemical bond dissociating and is expected to have an adsorbing effect due to the effect of retaining liquid electrolyte of $\mathrm{MgO}$ in a Li/iron sulfide secondary battery, ${ }^{16}$ was prepared by the sol-gel method as an electrochemically inactive additive for an elemental sulfur cathode for Li/S rechargeable batteries. The Li/S battery using an elemental sulfur cathode with a nanosized $\mathrm{Mg}_{0.6} \mathrm{Ni}_{0.4} \mathrm{O}$ added showed the improvement of not only the discharge capacity but also cycle durability (maximum discharge capacity: $1185 \mathrm{mAh} / \mathrm{g}$ sulfur, $\mathrm{C}_{50} / \mathrm{C}_{1}=85 \%$ ). The rate capability of the sulfur cathode was also increased with the addition of the nanosized $\mathrm{Mg}_{0.6} \mathrm{Ni}_{0.4} \mathrm{O}$. From the results, it is confirmed that the nanosized $\mathrm{Mg}_{0.6} \mathrm{Ni}_{0.4} \mathrm{O}$ had the polysulfide adsorbing effect and the catalytic effect of promoting Li/S redox reaction. Furthermore, it is found that the nanosized $\mathrm{Mg}_{0.6} \mathrm{Ni}_{0.4} \mathrm{O}$ also increased the porosity of the sulfur cathode.

(C) 2004 The Electrochemical Society. [DOI: 10.1149/1.1710895] All rights reserved.

Manuscript submitted May 30, 2003; revised manuscript received December 15, 2003. Available electronically April $26,2004$.

The rapid growth of portable electronic devices such as notebook computers, camcorders, and cellular phones has required the development of rechargeable lithium batteries with a higher specific capacity and energy density. The $\mathrm{Li} / \mathrm{S}$ battery is a very attractive candidate for rechargeable lithium batteries due to its high theoretical specific capacity of $1672 \mathrm{mAh} / \mathrm{g}$ and theoretical energy density of $2600 \mathrm{Wh} / \mathrm{kg}$ based on sulfur active material. ${ }^{1}$ Moreover, utilization of sulfur is advantageous because of its low cost and nontoxicity. ${ }^{2}$

Due to these advantages, Li/S batteries have been studied by many researchers with a view toward practical application. ${ }^{3-6}$ However, the development of $\mathrm{Li} / \mathrm{S}$ batteries has encountered difficulties due to poor cycle life at room temperature. Hence, in order to improve cycle life, it is necessary to elucidate the degradation mechanism of the $\mathrm{Li} / \mathrm{S}$ battery and prevent it.

The discharge process of the $\mathrm{Li} / \mathrm{S}$ battery proceeds by two steps. The first step is the transformation of sulfur to lithium polysulfide $\left(\mathrm{Li}_{2} \mathrm{Sn}, 2<n<8\right)$, and the second step is the change of lithium polysulfide to lithium sulfide $\left(\mathrm{Li}_{2} \mathrm{~S}\right) \cdot{ }^{6-8}$ It was reported that the lithium polysulfide which forms during the first discharge step of a $\mathrm{Li} / \mathrm{S}$ battery dissolves into electrolyte, which causes the irreversible loss of sulfur active material. ${ }^{8-13}$ Recently, Nimon and co-workers have suggested that when polysulfide dissolved into electrolyte diffuses to the lithium anode and then reacts with the lithium metal anode it drastically decreases lithium cycling efficiency. ${ }^{14}$ Thus, it can be concluded that the cyclic behavior of a $\mathrm{Li} / \mathrm{S}$ battery is very poor mainly due to polysulfide dissolution into the electrolyte.

To overcome this problem, polysulfide dissolution into electrolyte should be retarded or prohibited. Of late, use of strong adsorption of the polysulfide to additive material such as vanadium oxides, silicates, aluminum oxide, and transition metal chalcogenides has been suggested. ${ }^{15}$ However, this adsorbing material is not very effective for improving cycle life, possibly due to its larger particle size and its insulating property lowering the kinetic property of the $\mathrm{Li} / \mathrm{S}$ battery.

In order to adsorb the polysulfide effectively without a decrease in kinetic property of the $\mathrm{Li} / \mathrm{S}$ battery, nanosized $\mathrm{Mg}_{0.6} \mathrm{Ni}_{0.4} \mathrm{O}$ prepared by the sol-gel method has been used as an additive. Although

* Electrochemical Society Active Member

z E-mail: jailee@mail.kaist.ac.kr the polysulfide adsorbing effect of the nanosized $\mathrm{Mg}_{0.6} \mathrm{Ni}_{0.4} \mathrm{O}$ has not been reported, it is expected to have the polysulfide adsorbing effect because $\mathrm{MgO}$, which has the same crystal structure as $\mathrm{Mg}_{0.6} \mathrm{Ni}_{0.4} \mathrm{O}$, had the effect of retaining liquid electrolyte in a $\mathrm{Li}$ /iron sulfide secondary battery like an electrolyte sponge. ${ }^{16}$ In addition, $\mathrm{Mg}_{0.6} \mathrm{Ni}_{0.4} \mathrm{O}$ has been reported to have a catalytic effect of dissociating the chemical bond (e.g., $\mathrm{N}=\mathrm{O}$; bond dissociation energy 607 $\mathrm{kJ} / \mathrm{mol}){ }^{17}$ Thus, this catalytic effect of $\mathrm{Mg}_{0.6} \mathrm{Ni}_{0.4} \mathrm{O}$ can be applied to the $\mathrm{Li} / \mathrm{S}$ battery considering the dissociation energy of the $\mathrm{S}-\mathrm{S}$ single bond $(255 \mathrm{~kJ} / \mathrm{mol})$.

In this work, nanosized $\mathrm{Mg}_{0.6} \mathrm{Ni}_{0.4} \mathrm{O}$ prepared by the sol-gel method was mixed with sulfur cathode materials by ballmilling and the effects of the nanosized $\mathrm{Mg}_{0.6} \mathrm{Ni}_{0.4} \mathrm{O}$ on the sulfur cathode were investigated.

\section{Experimental}

Preparation of nanosized $\mathrm{Mg}_{0.6} \mathrm{Ni}_{0.4} \mathrm{O}$.- - Nanosized $\mathrm{Mg}_{0.6} \mathrm{Ni}_{0.4} \mathrm{O}$ powders were prepared by the sol-gel method (Fig. 1). $11.6 \mathrm{~g}$ nickel(II) nitrate $\cdot 6 \mathrm{H}_{2} \mathrm{O}$ (Aldrich), $15.4 \mathrm{~g}$ magnesium nitrate $6 \mathrm{H}_{2} \mathrm{O}$ (Aldrich), and $13 \mathrm{~g}$ citric acid (chelating agent) were dissolved in $150 \mathrm{~mL}$ deionized water. The solution was stirred by a magnetic bar and evaporated at moderate temperature. The solid samples (wet-gel state, green color) were calcined at $700^{\circ} \mathrm{C}$ for $5 \mathrm{~h}$ and then $\mathrm{Mg}_{0.6} \mathrm{Ni}_{0.4} \mathrm{O}$ powders were ground in air. Finally, the powders were synthesized in a $\mathrm{H}_{2}$ atmosphere at $700-800^{\circ} \mathrm{C}$ for $1 \mathrm{~h}$.

Preparation of the sulfur cathode and coin-type cell.-Sulfur cathode slurry was prepared by mixing with $20 \mathrm{wt} \%$ elemental sulfur (Aldrich, $\sim 80 \mu \mathrm{m}, 99.98 \%$ ) as an active material, $55 \mathrm{wt} \%$ acetylene black, 15 wt $\%$ nanosized $\mathrm{Mg}_{0.6} \mathrm{Ni}_{0.4} \mathrm{O}$ additive through ballmilling (SPEX-8000 mixer/mill, high-energy mill), and then adding $10 \mathrm{wt} \%$ polyvinylidene fluoride $(\mathrm{PVdF})$ dissolved in $\mathrm{N}$-methyl-2-pyrrolidene (NMP) solution to the mixture. Sulfur cathode slurry without nanosized $\mathrm{Mg}_{0.6} \mathrm{Ni}_{0.4} \mathrm{O}$ additives $(20 \mathrm{wt} \%$ elemental sulfur, $70 \mathrm{wt} \%$ acetylene black, and $10 \mathrm{wt} \% \mathrm{PVdF}$ in NMP solution) was also prepared in the same way described previously. The slurries of the cathode were coated on Al foil substrates, and then the cathodes were dried at $80^{\circ} \mathrm{C}$ for $24 \mathrm{~h}$ in a vacuum oven After vacuum drying, the sulfur cathodes were cut into a $1 \times 1 \mathrm{~cm}$ size. Coin-type cells were assembled in an Ar-filled glove box by 


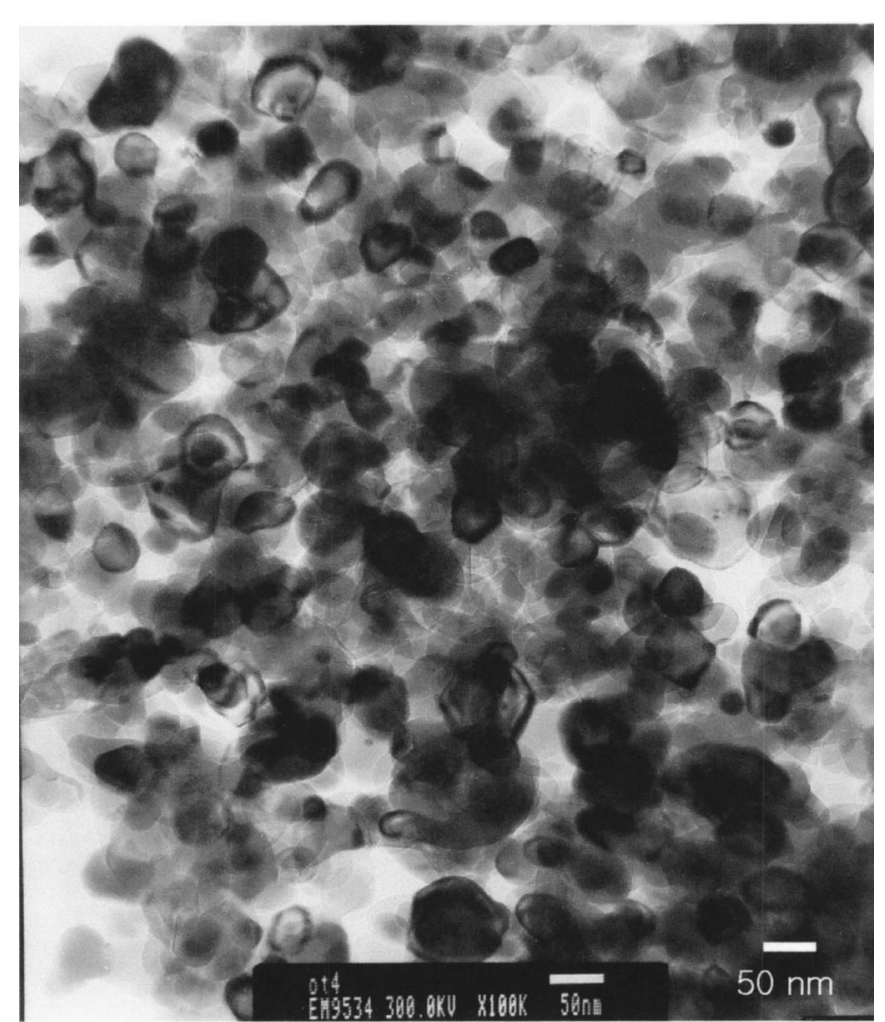

Figure 1. TEM image of $\mathrm{Mg}_{0.6} \mathrm{Ni}_{0.4} \mathrm{O}$.

stacking a porous polypropylene (Celgard 2200) separator containing liquid electrolyte between the sulfur cathode and the lithium metal foil anode (Cyprus Foote Mineral, 99.98\%, USA). The solution of $1 \mathrm{M}$ LiTFSI in [tri(ethylene glycol) dimethyl ether] (Triglyme) poly(ethylene glycol) dimethyl ether (PEGDME) 250, and PEGDME 500 were used as a liquid electrolyte.

Electrochemical and structural analysis.-The cells were discharged and charged galvanostatically, and the rest time between discharging and charging was $5 \mathrm{~min}$. The electrodes were discharged at $0.1 \mathrm{C}$ rate to $1.5 \mathrm{~V}$ and charged at $0.1 \mathrm{C}$ rate up to $3.5 \mathrm{~V} v s . \mathrm{Li} / \mathrm{Li}^{+}$ at room temperature.

The cyclic voltammetry (CV) measurement was performed using an EG\&G Princeton Applied Research potentiostat/galvanostat. The potential sweep rate was $0.1 \mathrm{mV} / \mathrm{s}$ and the voltage range was between 3.5 and $1.5 \mathrm{~V}$.

The structural analysis was characterized using X-ray diffraction (XRD, Rigaku Co.). The morphology of nanosized $\mathrm{Mg}_{0.6} \mathrm{Ni}_{0.4} \mathrm{O}$ additives prepared by the sol-gel method, and the cathode was characterized by scanning electron microscopy (SEM, Philips) and JEOL transmission electron microscopy (TEM). The porosity considering only the open pores of the cathode was measured by BrunauerEmmett-Teller (BET) measurement with nitrogen gas. Prior to measurements, all samples were heated at $300^{\circ} \mathrm{C}$ for $10 \mathrm{~h}$ under vacuum to remove surface-adsorbed species such as $\mathrm{H}_{2} \mathrm{O}$ and hydrocarbons.

Measurement of quantity of sulfur dissolution in electrolyte.-The coin-type cell after cycling was disassembled and immersed into the same solvent as the one used in the cell. After stirring for complete homogenization, the quantity of sulfur dissolved in the liquid electrolyte after cycling was measured by using a sulfur analyzer (SC-432DR).

\section{Results and Discussion}

Structural and electrochemical analysis of nanosized $M g_{0.6} \mathrm{Ni}_{0.4} \mathrm{O}$ additive.-Figure 1 shows the TEM image of (b)

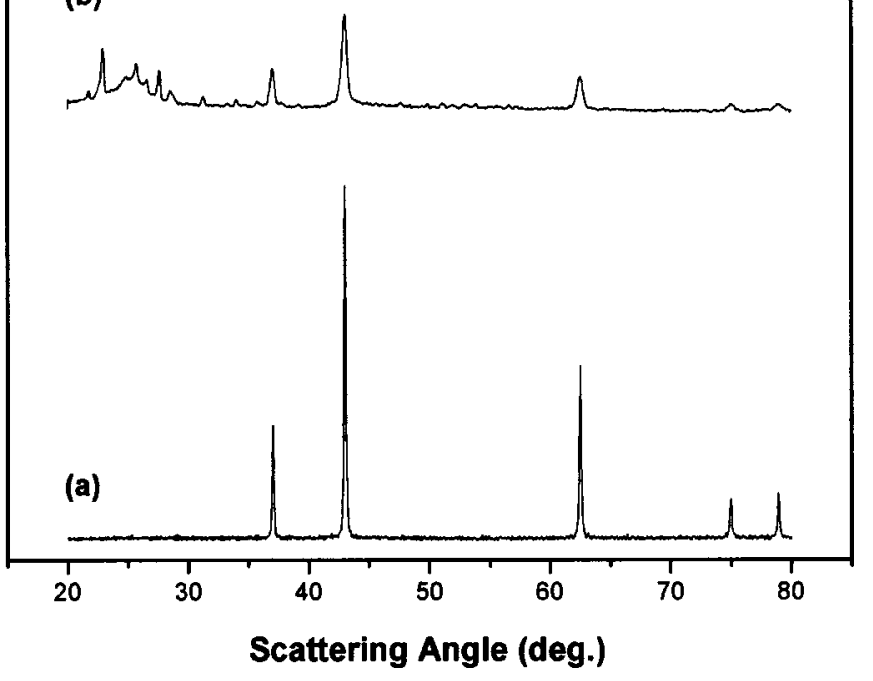

Figure 2. XRD profiles: (a) $\mathrm{Mg}_{0.6} \mathrm{Ni}_{0.4} \mathrm{O}$ powders and (b) a mixture of sulfur, acetylene black, and $\mathrm{Mg}_{0.6} \mathrm{Ni}_{0.4} \mathrm{O}$ after ballmilling.

$\mathrm{Mg}_{0.6} \mathrm{Ni}_{0.4} \mathrm{O}$ additives prepared by the sol-gel method. The particle size of $\mathrm{Mg}_{0.6} \mathrm{Ni}_{0.4} \mathrm{O}$ additives was about 30-50 nm (nanosized) and they had a round shape. These nanosized particles of $\mathrm{Mg}_{0.6} \mathrm{Ni}_{0.4} \mathrm{O}$ were very effective for maximizing their effects as an additive on the sulfur cathode due to their high specific surface area.

$\mathrm{XRD}$ analysis has been carried out to investigate whether during the mixing of cathode materials, the $\mathrm{Mg}_{0.6} \mathrm{Ni}_{0.4} \mathrm{O}$ additives reacted with other cathode components or not (Fig. 2). It can be seen in Fig. 2 that the XRD peaks of $\mathrm{Mg}_{0.6} \mathrm{Ni}_{0.4} \mathrm{O}$ are still present after nanosized $\mathrm{Mg}_{0.6} \mathrm{Ni}_{0.4} \mathrm{O}$ additives are mixed with sulfur and acetylene black powders by ballmilling, and these XRD data indicate that there is no reaction between $\mathrm{Mg}_{0.6} \mathrm{Ni}_{0.4} \mathrm{O}$ additives and other cathode components.

$\mathrm{CV}$ of the Li/S battery is shown in Fig. 3. Two well-defined reduction and oxidation peaks for the $\mathrm{Li} / \mathrm{S}$ battery without $\mathrm{Mg}_{0.6} \mathrm{Ni}_{0.4} \mathrm{O}$ additives existed distinctly. In the case of the sulfur cathode with $\mathrm{Mg}_{0.6} \mathrm{Ni}_{0.4} \mathrm{O}$ additives, there were also only two reduc-

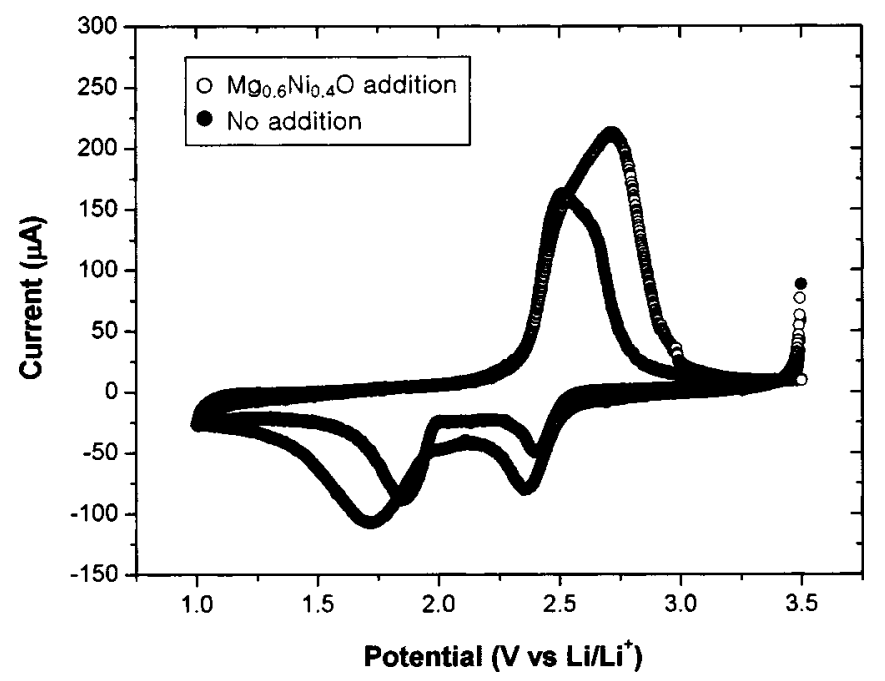

Figure 3. CV curves of Li/S battery with $1 \mathrm{M}$ LiTFSI in PEGDME 500 as electrolyte. Potential sweep rate $0.1 \mathrm{mV} / \mathrm{s}$ and voltage range between 3.5 and $1.0 \mathrm{~V}$ vs. $\mathrm{Li} / \mathrm{Li}^{+}$at room temperature $\left(30^{\circ} \mathrm{C}\right)$. 


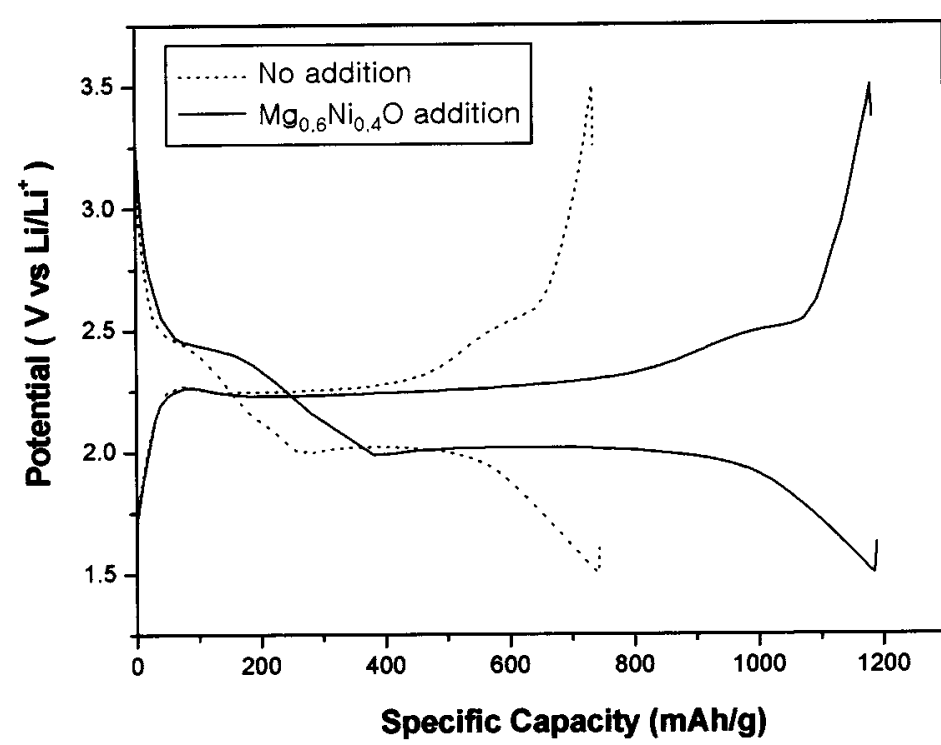

Figure 4. Initial charge-discharge behaviors of $\mathrm{Li} / \mathrm{S}$ battery using $1 \mathrm{M}$ LITFSI in PEGDME 500 as a electrolyte at room temperature.

tion and oxidation peaks which were slightly shifted to lower and higher potential, respectively. This means that nanosized $\mathrm{Mg}_{0.6} \mathrm{Ni}_{0.4} \mathrm{O}$ additives are electrochemically inactive materials which do not participate in the charge-discharge process of the $\mathrm{Li} / \mathrm{S}$ battery.

Charge-discharge characteristics of nanosized $\mathrm{Mg}_{0.6} \mathrm{Ni}_{0.4} \mathrm{O}$ added to Li/S batteries. - The charge-discharge test was performed in order to investigate the changes of the electrochemical properties of the $\mathrm{Li} / \mathrm{S}$ battery after application of $\mathrm{Mg}_{0.6} \mathrm{Ni}_{0.4} \mathrm{O}$ additives. Figure 4 presents the initial charge-discharge curves of the Li/S battery at room temperature. The discharge curve shows two typical plateaus at about 2.4 (short upper plateau) and $2.0 \mathrm{~V}$ (long lower plateau), respectively. The upper one, $2.4 \mathrm{~V}$, was reported as a polysulfide $\left(\mathrm{Li}_{2} \mathrm{~S}_{8}, \mathrm{Li}_{2} \mathrm{~S}_{6}, \mathrm{Li}_{2} \mathrm{~S}_{4}, \mathrm{Li}_{2} \mathrm{~S}_{2}\right.$ ) formation potential, and the lower one, $2.0 \mathrm{~V}$, was known as a $\mathrm{Li}_{2} \mathrm{~S}$ formation potential. ${ }^{6-8}$ Interestingly, it is found in Fig. 4 that the initial charge-discharge capacity is increased from 741 to $1185 \mathrm{mAh} / \mathrm{g}$ sulfur after addition of nanosized $\mathrm{Mg}_{0.6} \mathrm{Ni}_{0.4} \mathrm{O}$ additives, and the lower plateau is more extended compared with the upper plateau. Furthermore, the cyclic durability of the cell was also improved from $76 \%$ of the initial discharge capacity at the 50th cycle to $85 \%$ (Fig. 5). The improvement of capacity and cyclic durability of the Li/S battery can be attained by solving the polysulfide dissolution problem. ${ }^{8-14}$ Thus, these results imply that the nanosized $\mathrm{Mg}_{0.6} \mathrm{Ni}_{0.4} \mathrm{O}$ additives prevent and retard the polysulfide dissolution into the liquid electrolyte by adsorbing polysulfides physically within the sulfur cathode.

Effects of nanosized $\mathrm{Mg}_{0.6} \mathrm{Ni}_{0.4} \mathrm{O}$ additives on $\mathrm{Li} / \mathrm{S}$ batteries.-For the purpose of examining the polysulfide adsorbing effect of $\mathrm{Mg}_{0.6} \mathrm{Ni}_{0.4} \mathrm{O}$ additives directly, sulfur quantitative analysis was conducted. Figure 6 shows the amount of sulfur dissolved in the liquid electrolyte with cycling. It is observed in Fig. 6 that after the addition of $\mathrm{Mg}_{0.6} \mathrm{Ni}_{0.4} \mathrm{O}$ additives, the content of dissolved sulfur by the form of polysulfide is lower than before. This result demonstrates directly that nanosized $\mathrm{Mg}_{0.6} \mathrm{Ni}_{0.4} \mathrm{O}$ additives have a polysulfide adsorbing effect in the Li/S battery.

Figure 7 and 8 also confirm that nanosized $\mathrm{Mg}_{0.6} \mathrm{Ni}_{0.4} \mathrm{O}$ additives retain polysulfide within the sulfur cathode. They display the charge-discharge curves of the Li/S battery using the sulfur cathode without and with $\mathrm{Mg}_{0.6} \mathrm{Ni}_{0.4} \mathrm{O}$ additives and $1 \mathrm{M}$ LiTFSI in Triglyme solution as an electrolyte. Charge-discharge curves in Fig. 7 clearly show a decrease in discharge capacity and an imperfect charging, which is known as the shuttle mechanism, ${ }^{18}$ taking place at around

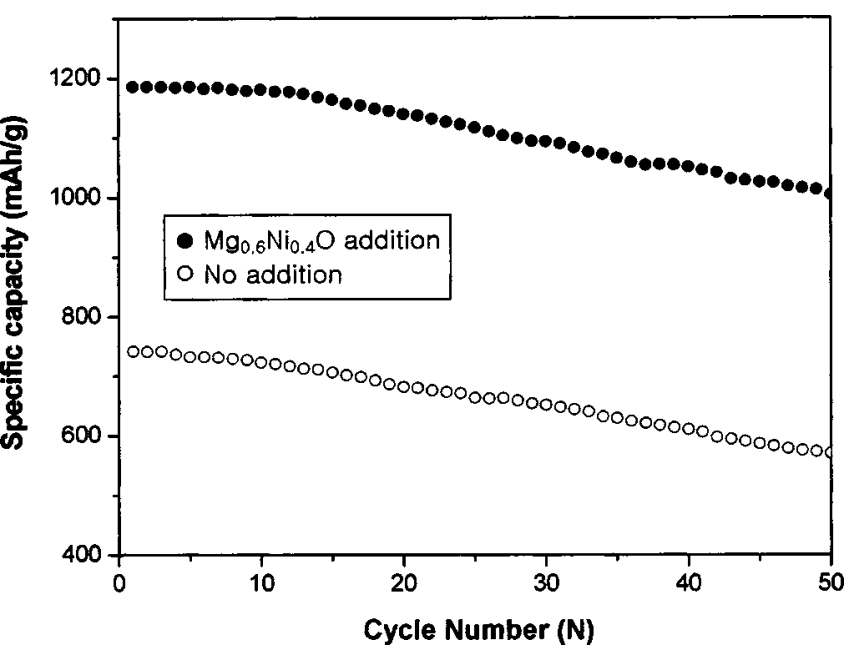

Figure 5. Cycle life of Li/S battery using 1 M LiTFSI in PEGDME 500 as electrolyte at room temperature.

$2.4 \mathrm{~V}$ at the first cycle during the charge process. During the charges, the higher order polysulfides (e.g., $\mathrm{Li}_{2} \mathrm{~S}_{8}, \mathrm{Li}_{2} \mathrm{~S}_{6}$ ), which are generated at the sulfur cathode during the upper voltage plateau stages of the charge, diffuse to the lithium electrode and react directly with the lithium in a parasitic reaction to recreate the lower order polysulfides. These species diffuse back to the sulfur cathode to generate the higher forms of polysulfide again, thus triggering a shuttle mechanism. Once the shuttle mechanism is started, as can be seen in Fig. 7, the charging behavior at about $2.4 \mathrm{~V}$ continues without overcharging, resulting in a decrease in charge efficiency at the end of the charge and the discharge capacity is reduced. In order to prevent this phenomenon, it is important to lower the content of polysulfides in the electrolyte because the shuttle mechanism can occur when the content of polysulfides in the electrolyte approaches a certain level.

It is found from Fig. 8 that addition of nanosized $\mathrm{Mg}_{0.6} \mathrm{Ni}_{0.4} \mathrm{O}$ additives to the sulfur cathode prohibits the shuttle mechanism. In Fig. 8, the cell voltage sharply increases up to $3.5 \mathrm{~V}$ via the upper voltage plateau of about $2.4 \mathrm{~V}$ during the charge process, and the capacity of the cell increases from 648 (no $\mathrm{Mg}_{0.6} \mathrm{Ni}_{0.4} \mathrm{O}$ additives addition) to $1180 \mathrm{mAh} / \mathrm{g}$ sulfur.

Figure 9 represents the cycle life of the Li/S battery at room temperature according to the addition of $\mathrm{Mg}_{0.6} \mathrm{Ni}_{0.4} \mathrm{O}$ additives. By

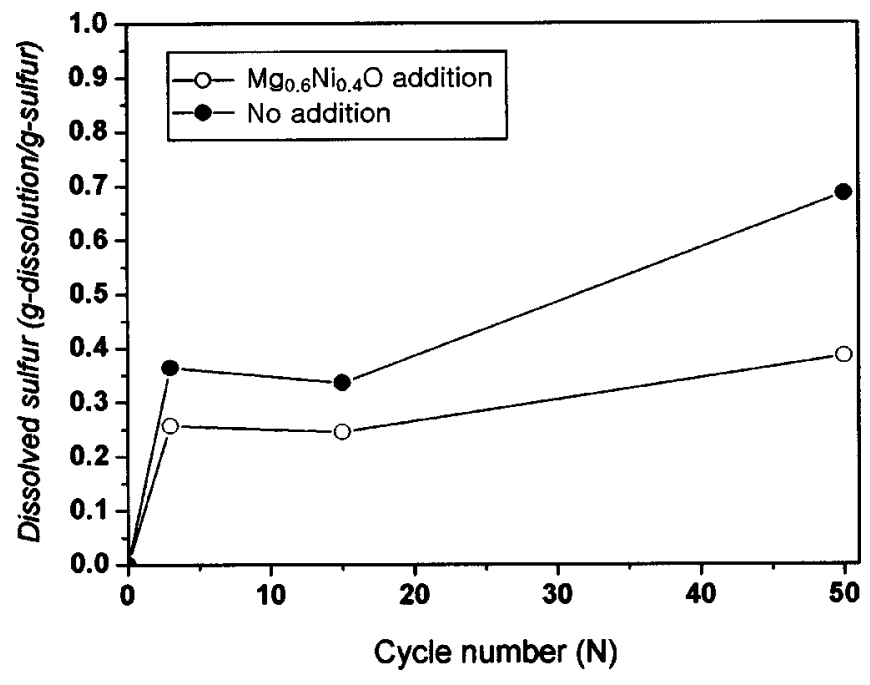

Figure 6. Amount of sulfur dissolved in the liquid electrolyte with cycling. 


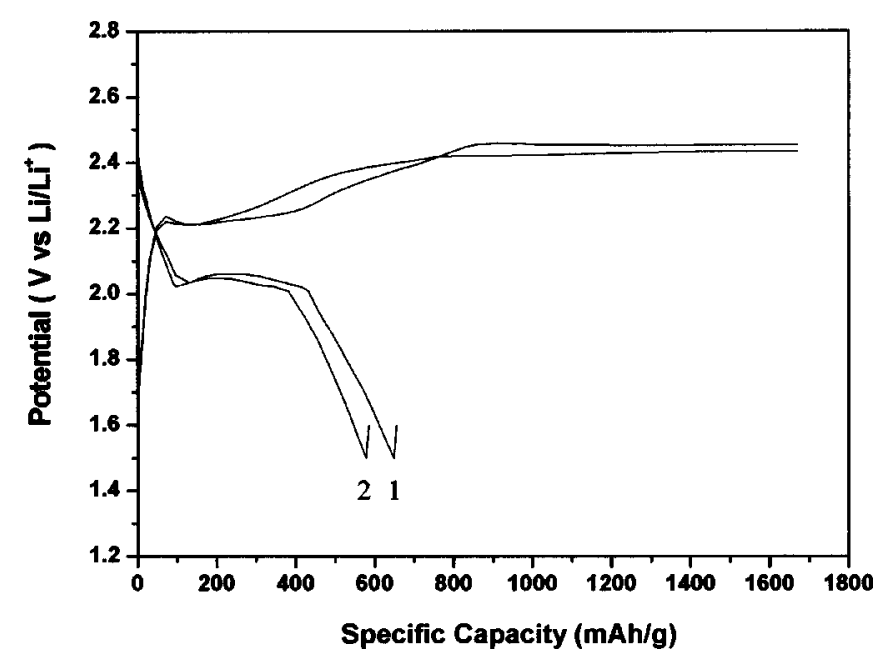

Figure 7. Charge-discharge profiles of Li/S battery using $1 \mathrm{M}$ LiTFSI in Triglyme as electrolyte.

applying nanosized $\mathrm{Mg}_{0.6} \mathrm{Ni}_{0.4} \mathrm{O}$ additives to the sulfur cathode, the improvement of cyclic durability was observed in Fig. 9. However, a degree of the improvement of cyclic durability (51\% of initial discharge capacity at the 50th cycle) is smaller than that presented in Fig. 5. The reason for this may be that in contrast to Triglyme, PEGDME 500 does not show the shuttle behavior due to its higher viscosity that can retard the polysulfide dissolution into the electrolyte. The data shown in Fig. 7-9 also prove, like the result of the sulfur quantitative analysis (Fig. 6), that the nanosized $\mathrm{Mg}_{0.6} \mathrm{Ni}_{0.4} \mathrm{O}$ additives have the polysulfide adsorbing effect.

Figure 10 shows the rate capability of the $\mathrm{Li} / \mathrm{S}$ battery. The rate capability for the $\mathrm{Li} / \mathrm{S}$ battery with nanosized $\mathrm{Mg}_{0.6} \mathrm{Ni}_{0.4} \mathrm{O}$ additives was slightly improved compared with one without $\mathrm{Mg}_{0.6} \mathrm{Ni}_{0.4} \mathrm{O}$ additives. This result implies that the velocity of the Li/S redox reaction is more rapid because rate capability is related to the kinetic property of the cell. Therefore, it is concluded that the catalytic effect of $\mathrm{Mg}_{0.6} \mathrm{Ni}_{0.4} \mathrm{O}$ additives works in the $\mathrm{Li} / \mathrm{S}$ battery.

Figure 11 displays the discharge curve of the Li/S battery using nanosized $\mathrm{Mg}_{0.6} \mathrm{Ni}_{0.4} \mathrm{O}$ additives and PEGDME 500. In Fig. 11 it can be seen that by adding the additives to the cathode, the upper voltage plateau is increased. Because the upper voltage plateau is known as a region where the sulfur is converted into polysulfides, ${ }^{6-8}$

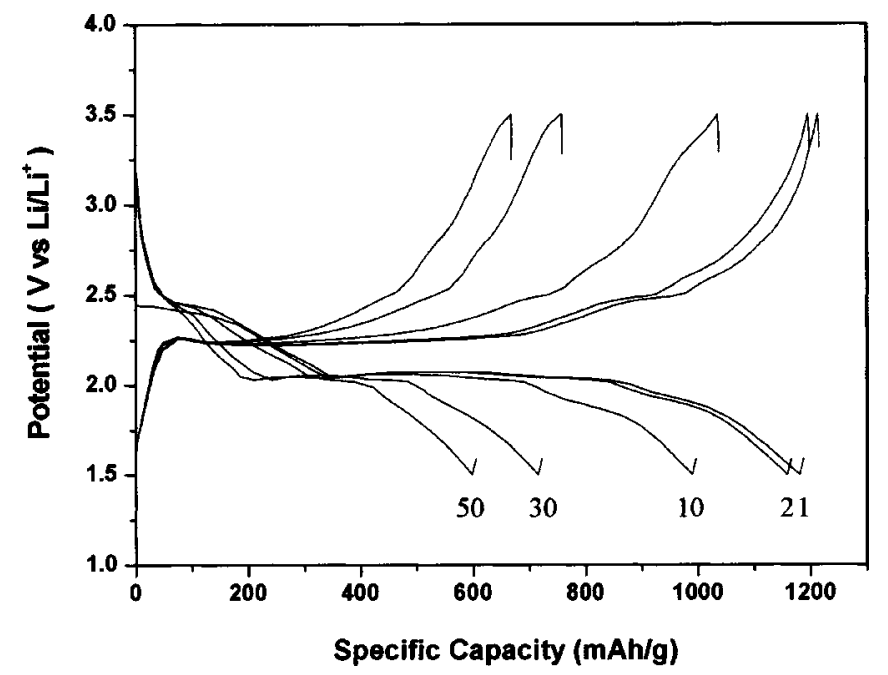

Figure 8. Charge-discharge behaviors of nanosized- $\mathrm{Mg}_{0.6} \mathrm{Ni}_{0.4} \mathrm{O}$-added $\mathrm{Li} / \mathrm{S}$ battery using $1 \mathrm{M}$ LiTFSI in Triglyme as a electrolyte.

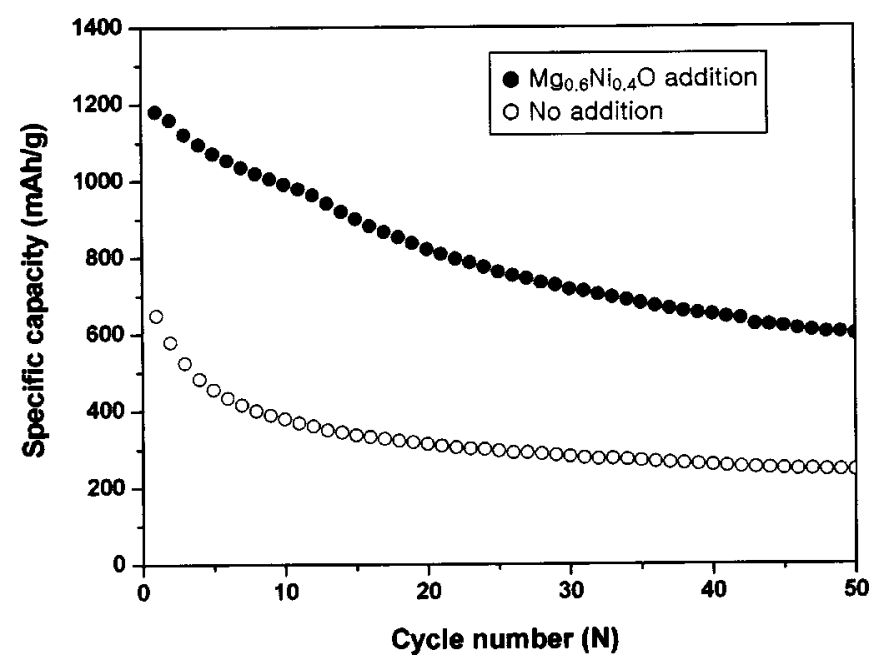

Figure 9. Cycle life of Li/S battery containing $1 \mathrm{M}$ LiTFSI in Triglyme as electrolyte at room temperature.

this phenomenon has no relation to the polysulfide adsorbing effect of the additives and therefore means that the electrochemically reactive sites where sulfur can react with lithium are increased. Hence, nanosized $\mathrm{Mg}_{0.6} \mathrm{Ni}_{0.4} \mathrm{O}$ additives have other effects besides the polysulfide adsorbing and catalytic effects.

BET surface area analysis was performed to measure the porosity of only open pores in the cathode. Table I displays the BET surface area of the sulfur cathode. Compared with the cathode containing no additives, the BET surface area of the sulfur cathode with the $\mathrm{Mg}_{0.6} \mathrm{Ni}_{0.4} \mathrm{O}$ additives increased almost twice, signifying that the nanosized $\mathrm{Mg}_{0.6} \mathrm{Ni}_{0.4} \mathrm{O}$ additives play a part of increasing the porosity of the sulfur cathode. An increase in the BET surface area (i.e., the porosity of open pores which are the permeation routes of liquid electrolyte) of the sulfur cathode is important for liquid electrolyte, batteries because easy and uniform penetration of the liquid electrolyte into the sulfur cathode improves the electrochemical properties of the $\mathrm{Li} / \mathrm{S}$ battery. Therefore, it is thought that an increase in porosity of open pores after addition of the nanosized $\mathrm{Mg}_{0.6} \mathrm{Ni}_{0.4} \mathrm{O}$ contributes to the increment of the upper voltage plateau of the discharge profile, which results in increasing capacity of the Li/S battery.

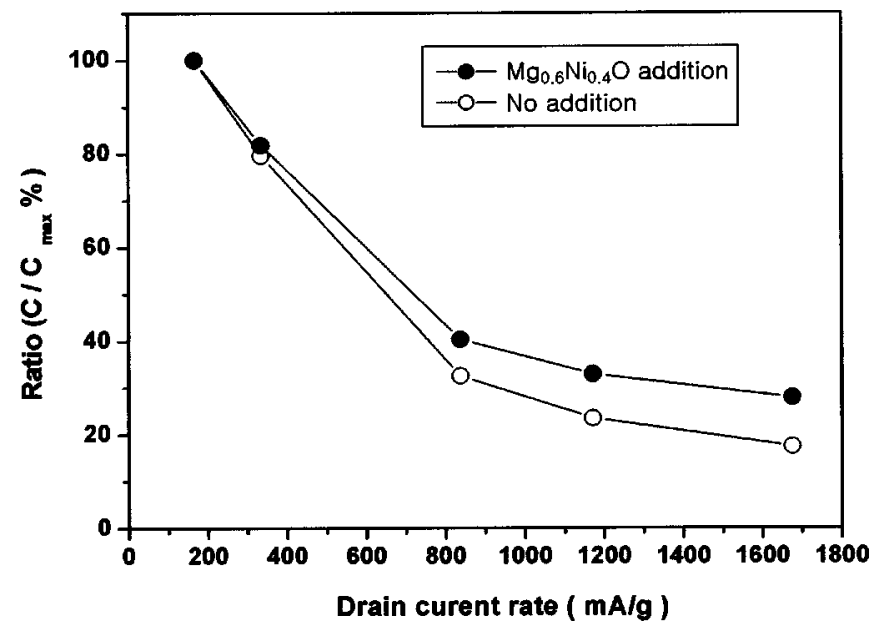

Figure 10. Rate capability of Li/S cell with 1 M LiTFSI in PEGDME 500 as electrolyte. Current density varies from 167.5 to $1675 \mathrm{~mA} / \mathrm{g}$ sulfur. 


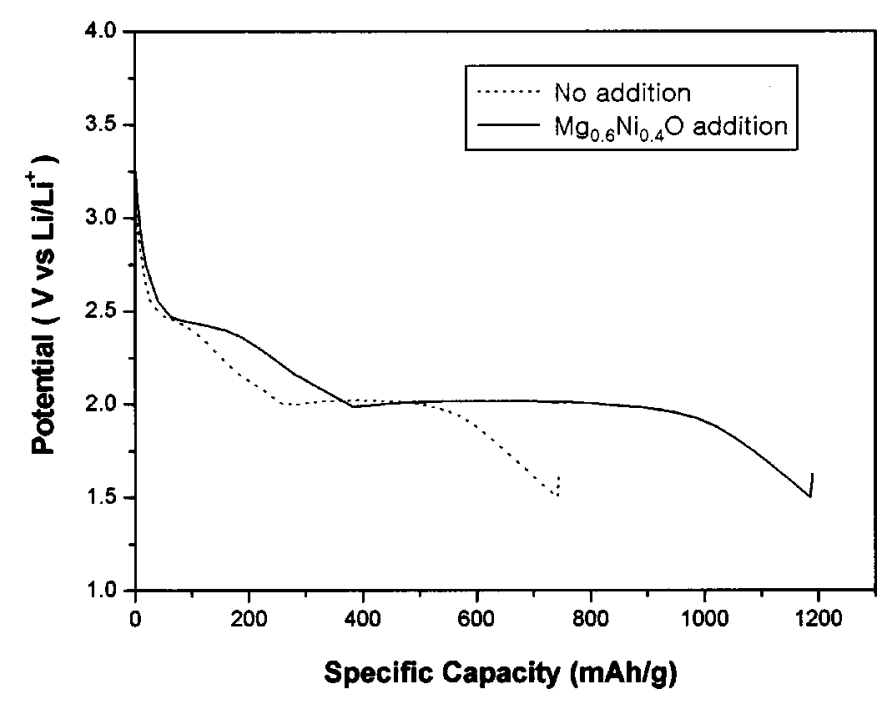

Figure 11. Discharge curves of Li/S battery with $1 \mathrm{M}$ LiTFSI in PEGDME 500 as electrolyte at room temperature.

\section{Conclusions}

Nanosized $\mathrm{Mg}_{0.6} \mathrm{Ni}_{0.4} \mathrm{O}$ powders were synthesized by the sol-gel method and added to the sulfur cathode. From the data here, it was found for the first time that these $\mathrm{Mg}_{0.6} \mathrm{Ni}_{0.4} \mathrm{O}$ powders used as an additive in sulfur cathodes retained the soluble polysulfides effectively within the cathode compared with other additives reported previously and increased the rate capability and porosity of the sulfur cathode. Furthermore, by adsorbing the polysulfides within the cathode, $\mathrm{Mg}_{0.6} \mathrm{Ni}_{0.4} \mathrm{O}$ additives prevented the shuttle behavior of the

Table I. BET surface area of the sulfur cathode.
Sulfur cathode

No $\mathrm{Mg}_{0.6} \mathrm{Ni}_{0.4} \mathrm{O}$ added

$\mathrm{Mg}_{0.6} \mathrm{Ni}_{0.4} \mathrm{O}$ added
Surface area of cathode $\left(\mathrm{m}^{2} / \mathrm{g}\right)$
$\mathrm{Li} / \mathrm{S}$ battery using Triglyme as an electrolyte. Because of these effects of $\mathrm{Mg}_{0.6} \mathrm{Ni}_{0.4} \mathrm{O}$ additives, the capacity and cyclic durability of the $\mathrm{Li} / \mathrm{S}$ battery at room temperature was improved simultaneously. All the effects of $\mathrm{Mg}_{0.6} \mathrm{Ni}_{0.4} \mathrm{O}$ additives mentioned in this work were thought to be maximized by the nanosize (30-50 nm) of $\mathrm{Mg}_{0.6} \mathrm{Ni}_{0.4} \mathrm{O}$ particles. Consequently, nanosized $\mathrm{Mg}_{0.6} \mathrm{Ni}_{0.4} \mathrm{O}$ is a good candidate as an additive for high-performance $\mathrm{Li} / \mathrm{S}$ batteries.

\section{Acknowledgments}

This work was supported by grant no. R01-1999-000-00184-0 from the interdisciplinary research program of KOSEF. The authors express their thanks for financial support from KOSEF. This work was also supported in part by the KAIST Chair Fund from the Korea Telecom Endowment.

The Korea Advanced Institute of Science and Technology assisted in meeting the publication costs of this article.

\section{References}

1. M.-Y. Chu, U.S. Pat. $5,814,420$ (1998).

2. T. Skotheim, U.S. Pat. 5,601,947 (1997).

3. M.-Y. Chu, U.S. Pat. 5,516,598 (1996).

4. R. D. Rauh, K. M. Abraham, G. F. Pearson, J. K. Surprenant, and S. B. Brummer, J. Electrochem. Soc., 126, 523 (1979).

5. H. Yamin and E. Peled, J. Power Sources, 9, 281 (1983).

6. H. Yamin, A. Gorenshtein, J. Penciner, Y. Sternberg, and E. Peled, J. Electrochem. Soc., 135, 1045 (1988).

7. H. Yamin, J. Penciner, A. Gorenshtain, M. Elam, and E. Peled, J. Power Sources, 14, 129 (1985).

8. D. Marmorstein, T. H. Yu, K. A. Striebel, and E. J. Cairns, J. Power Sources, 89 , 219 (2000).

9. P. Degott, Ph.D. Thesis, l'Institut National Polytechnique de Grenoble, France (1986).

10. M.-Y. Chu, U.S. Pat. 5,523,179 (1996).

11. G. Eichinger and J. Besenhard, J. Electroanal. Chem. Interfacial Electrochem., 72, 1 (1976).

12. D. W. Murphy and J. N. Carides, J. Electrochem. Soc., 126, 349 (1979).

13. C. B. Ho, Ph.D. Thesis, Korea Advance Institute of Science and Technology (2001).

14. E. S. Nimon, M. Sukeshini, and S. J. Visco, IMLB 2002, Poster presentation.

15. Gorkovenko, U.S. Pat. 6,210,831 B1 (2001).

16. G. L. Henriksen, T. Kaun, A. Jansen, and J. Prakash, in Molten Salts, P. C. Trulove, H. C. De Long, G. R. Stafford, and S. Deki, Editors, PV 98-11, p. 302, The Electrochemical Society Proceedings Series, Pennington, NJ (1998).

17. I. C. Vickerman, Catalysis Specialist Periodic Reports, Vol. 2, p. 107, The Chemical Society, London (1978)

18. Y. V. Mikhaylik and J. R. Akridge, J. Electrochem. Soc., 150, A306 (2003). 